\title{
A RAILWAY INVADER
}

Archie Budd, Swift Current, Saskatchewan

THERE are some plants which appear to have a particular affinity to railway tracks, and a species of Catchfly, Silene spp., is an outstanding example. This is the Smooth Catchfly, Silene Cserei, a plant growing from 12 to 24 inches high with clasping, opposite leaves from 1 to 3 inches long, which are oblong, smooth and thick. The inflorescence is an elongate, narrow panicle of two erect branches, with the flowers in whorls, with white petals and a pinkish, ovoid calyx about $1 / 2$ an inch long and constricted at the mouth. It is probably a biennial with a tap root, although some authorities list it as an annual and one monograph classes it as perennial. It much resembles Bladder Campion and our early collections were so labelled, but Bladider Campion is a perennial with running rootstocks, and with greenish, much inflated calyx, not much constricted at the mouth.

Smooth Catchfly has been collected in North Dakota as long ago as 1916 but was not plentiful then. It was found beside the railway east of Swift Current in 1939 and by $1944 \mathrm{Mr}$. Eastham found it very plentiful in the railway yards at Prince George, British Columbia. Now it is almost the dominant plant along the tracks in the vicinity of Swift Current and is spreading rapidly there.

\section{AN INTERESTING GROUP}

\author{
W. C. McCalla, Calgary
}

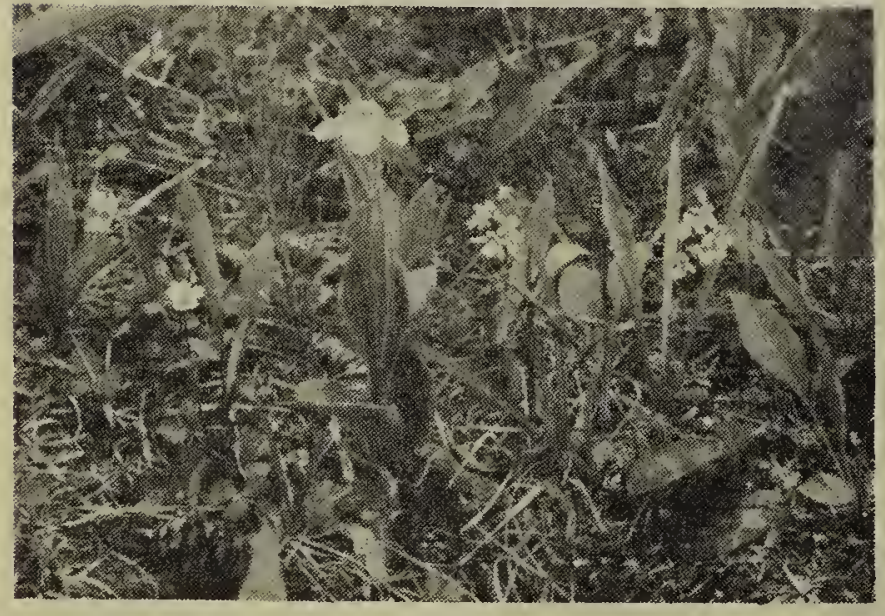

The photograph was taken by $\mathrm{Mr}$. McCalla at Banff. On the left is the Northern Anemone (Anemone parviflora), at the centre the North- ern Lady's Slipper (Cypripedium passerinum) and at the right two nice specimens of Orchis (Orchis rotundifolia).

"It is unusual," writes Mr. McCalla, "to find a single flowering stem of Cypripedium passerinum - they usually grow in clumps. This solitary 'queen' surrounded by lesser plants seemed worth recording."

"I wouldn't like to be without this very informative interesting magazine. It means more to me than any words I could use to express."

-Mrs. O. L. Wolters, Tolland, Alta. 